I sol at $i$ on and char act er i zat $i$ on of a bi osurfact ant-produci ng heavy net al resi st ant Rahnel I a sp. RM i sol at ed from chr omi um cont ami nat ed soi I

\begin{tabular}{|l|l|}
\hline 著者 & $\begin{array}{l}\text { GOVARTHANAN Mit husamy, MTH LI R. , SELVANKUMAR } \\
\text { Thangasamy, KAMALA- KANNAN S. CHO DuBok, } \\
\text { CHANG Young- Cheol }\end{array}$ \\
\hline $\begin{array}{l}\text { j our nal or } \\
\text { publ i cat i on t i t l e }\end{array}$ & Bi ot echnol ogy and Bi opr ocess Engi neer i ng \\
\hline vol une & 22 \\
\hline number & 2 \\
\hline page r ange & $186-194$ \\
\hline year & $2017-05-14$ \\
\hline URL & ht t p: //hdl . handl e. net /10258/00009598 \\
\hline
\end{tabular}




\section{Isolation and characterization of a biosurfactant-producing heavy metal resistant Rahnella sp. RM isolated from chromium-contaminated soil}

Muthusamy Govarthanan ${ }^{1}$, R. Mythili ${ }^{2}$, Thangasamy Selvankumar ${ }^{2}$, S. Kamala-Kannan ${ }^{3}$, Dubok Choi ${ }^{4, *}$, Young-Cheol Chang ${ }^{1, *}$

${ }^{1}$ Department of Applied Sciences, College of Environmental Technology, Muroran Institute of Technology, 27-1 Mizumoto, Muroran, Hokkaido 050-8585, Japan,

${ }^{2} \mathrm{PG} \&$ Research Department of Biotechnology, Mahendra Arts and Science College (Autonomous), Kalippatti, Namakkal - 637501, Tamil Nadu, India

${ }^{3}$ Division of Biotechnology, College of Environmental and Bioresource Sciences, Chonbuk National University, Iksan - 570752, South Korea

${ }^{4}$ Biotechnology Laboratory, B-K Company Ltd, Gusan 54008, South Korea

Running Title: Isolation and characterization of a biosurfactant-producing heavy metal resistant Rahnella sp. RM 
*Corresponding author E-mail address: choidubok@naver.com (D. B. Choi); ychang@mmm.muroran-it.ac.jp (Y.C. Chang) Tel.: 063-469-2548; FAX: 063-466-2984 Tel\&Fax: +81-143-46-5757

\begin{abstract}
Objective of the study was to isolate heavy metal resistant bacteria from chromiumcontaminated subsurface soil and investigate biosurfactant production and heavy metal bioremediation. Based on 16S rRNA gene sequence and phylogenetic analysis, the isolate was identified as Rahnella sp. RM. The biosurfactant production by heavy metal resistant Rahnella sp. RM was optimized using Box-Behnken design (BBD). The maximum emulsification activity was obtained $66 \%$ at $6 \%$ soybean meal in $\mathrm{pH} 7.0$ and $33.5{ }^{\circ} \mathrm{C}$. The biosurfactant was characterized using Field emission scanning electron microscopy (FESEM), Fourier transform infrared spectroscopy (FT-IR) and matrix assisted laser desorption/ionization time of flight mass spectrometry (MALDI-TOF). The highest metal removal rates using the biosurfactant were found $74.3,72.5$, and $70.1 \%$, respectively, at the $100 \mathrm{mg} / \mathrm{L}$ amended flasks at $48 \mathrm{~h}$. This study indicated the biosurfactant from heavy metal resistant Rahnella sp. RM could be used as a potential tool to remediate the metals in contaminated environments.
\end{abstract}


Keywords: Rahnella sp., emulsification activity, biosurfactant, heavy metal, bioremediation.

\section{Introduction}

The release of heavy metals into the earth is one of the major environmental pollution and has become an attention of great concern in the world due to the extensive release of metal(loid)s in soil and water [1]. Elimination of heavy metals from the contaminated soil is particularly challenging as these metals are non-biodegradable. Thus, development of remediation strategies for heavy metal polluted soil is important for ecological conservation and human health. Several physico-chemical methods have been developed to control the dispersion and biomagnification of metals from contaminated soil. However, the disadvantages and ineffectiveness of these methods have been widely reported [2-4]. An alternative to the application of phyisco-chemical methods in heavy metal removal from contaminated soil/water is the use of microorganisms, capable of reduce, immobilize, transform, and leach the metal(loid)s [5-7].

Bioremediation is considered as a simple, inexpensive, and eco-friendly technology that uses biotic communities for the remediation of contaminated soils. Microorganisms are primarily used in the bioremediation to degrade or detoxify the pollutants into harmless and less toxic forms. Several studies reported the bioremediation of metal(loid)s by using microorganisms [8-11]. In addition, the use of microbial metabolic products widely analysed new tool increasing the removal of metal(loid)s from contaminated soil/water. Among the metabolic products, biosurfactants have been widely investigated because of its multiple applications including metal(loid)s removal. 
Biosurfactants (BS) have been produced by microorganisms either extracellular or as part of the cell membrane from different substrates [12]. Several bacterial isolates belonging to the genus Bacillus, Pseudomonas, Arthrobacter, Micrococcus, and Rahnella have been reported as efficient BS producers [13-19]. However, the production of BS from heavy metal resistant Rahnella sp. is less informative. He et al. [20] reported that the endophytic Rahnella sp. JN6 effectively improve the efficiency of phytoremediation in soils contaminated by Cd, $\mathrm{Pb}$, and $\mathrm{Zn}$. Smułek et al. [21] reported that the biosurfactant production efficiency of Rahella sp. strain EK12 isolated from soil contaminated with crude oil. However, there are no reports about the removal of metals by BS producing heavy metal resistant Rahnella sp.

It has been established that the bacterial strains are very active in an optimal growth conditions and produce efficient amount of BS. Thus, the Box-Behnken design (BBD), a statistical tool employed for the media optimization leads to the enhanced production of BS. BBD employed for multiple regression analysis by using ANOVA and quantitative data obtained from the pre-designed experiments [22, 23]. Due to the potential use in environmental applications such as heavy metal removal, significant attention has been given in the past years to the production of surface active molecules from biological sources [24, 25]. In recent years the agricultural by-products have received much attention as potential substrates for the production of BS $[26,27]$. The microorganisms can easily utilize the agricultural by-products as a carbon and nitrogen source, and secrete the BS in the solid state fermentation medium. Yield of BS generally depends on nature of substrate and microbial source, therefore in current study a very distinctive nutrient source, soybean meal (SM) an agro industrial by-product obtained after oil is removed from soybean seeds, has been selected for the production of BS using a selectively isolated Rahnella sp., RM from chromium contaminated soil. The availability, nature of renewable source and rich nutrients properties attracts the use of SM as a substrate for the production of BS by fermentation. 
Hence, the objective of the study was to isolate heavy metal resistant bacteria from chromium-contaminated subsurface soil and investigate biosurfactant production and bioremediation of heavy metals using biosurfactant.

\section{Materials and methods}

\section{Isolation of BS producing bacteria}

Soil sample was collected from Ranipet, Tamil Nadu, India, a chromium contaminated site. The site is located at $12.9283^{\circ}$ latitude and $79.3325^{\circ}$ longitudes. Soil sample was serially diluted into saline $(0.85 \% \mathrm{NaCl})$ up to $10^{-8}$ dilution and plated using the spread plate technique onto nutrient agar (Hi-Media, India) plates. The plates were incubated at $35 \pm 2{ }^{\circ} \mathrm{C}$ for $24-48 \mathrm{~h}$ and observed the bacterial growth. Morphologically distinct colonies were selected and tested heavy metal resistance mechanism and biosurfactants producing capacity.

\section{Determination of minimal inhibitory concentration (MIC) of metals}

The metal resistance experiments were carried out in agar dilution method [27]. The log phase cultures of the isolates were aseptically inoculated onto nutrient agar plates amended with the metals $(\mathrm{Cr}, \mathrm{Pb}$, and $\mathrm{Cu})$. The inoculated plates were incubated at $33 \pm 2{ }^{\circ} \mathrm{C}$ for $24-48$ $\mathrm{h}$ and monitored the bacterial growth. The concentration of metal that completely inhibited the growth of the bacteria was considered as MIC.

\section{Screening of BS producing bacteria}

The biosurfactant producing bacteria was identified using oil displacement test [15] and emulsification assay [28]. The emulsification assay was performed based on the emulsification capacity of produced BS. The emulsification assay was calculated using emulsification index.

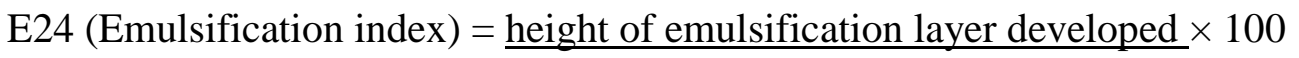

Total height of liquid medium 
Based on the MIC and BS screening results we have chosen the isolate RM for further experiments.

\section{S rRNA gene identification of the isolated bacteria}

Overnight grown bacterial cells from nutrient broth were harvested and chromosomal DNA was extracted according to the protocol developed by Qiagen, DNA extraction kit (QIAGEN, CA, USA). The 16S rRNA gene of the isolate was amplified using the primers, $27 \mathrm{f}$ ( $5^{\prime}$ AGA GTT TGA TCC TGG CTC AG 3') and 1492r (5' TAC GGY TAC CTT GTT ACG ACT T 3') in a thermocycler at $95{ }^{\circ} \mathrm{C}(5 \mathrm{~min})$ followed by 35 cycles at $94{ }^{\circ} \mathrm{C}(1 \mathrm{~min}), 49^{\circ} \mathrm{C}(2 \mathrm{~min})$, and $72{ }^{\circ} \mathrm{C}(2 \mathrm{~min})$ with a final extension temperature of $72{ }^{\circ} \mathrm{C}$ for $7 \mathrm{~min}$. The PCR product was purified using a PCR purification kit (QIAGEN, CA, USA) and sequenced using an automated ABI PRISM 3700 sequencer (USA). The sequences were compared using the BLAST program (http://www.ncbi.nlmnih.gov/BLAST) for identification of the isolate. Phylogenetic tree was constructed using neighbour-joining distance method by software Mega 6.0.

\section{Substrate preparation and growth kinetics}

Substrate soybean meal was procured from Mallasamudram, Tamil Nadu, India. The nutrient composition of the SM is presented in Table 1 [29]. SM was reconstituted in sterile distilled water $(100 \mathrm{~mL})$ at $200 \mathrm{rpm}$ for $5 \mathrm{~h}$, filtered through Whatman no.1 filter paper then membrane filter $(0.2 \mu \mathrm{m})$. The SM medium was used for growth of isolate and BS production. Accordingly, Log phase culture $(5 \mathrm{~mL})$ of the isolate RM was aseptically inoculated into the freshly prepared different concentration (1-5\%) of SM and growth was measured at the prescribed time intervals $(12-72 \mathrm{~h})$ in terms of increase in optical density at $600 \mathrm{~nm}$ using a UV-Vis spectrophotometer (UV-1800, Shimadzu, Japan).

\section{BS production}


The SM media was used for the production of BS. Briefly, the isolate RM (5 mL) was inoculated $\left(10^{8}\right.$ cells $\left.\mathrm{mL}^{-1}\right)$ into $500 \mathrm{~mL}$ Erlenmeyer flasks containing $100 \mathrm{~mL}$ SM medium and incubated at $35^{\circ} \mathrm{C}$ for $48 \mathrm{~h}(200 \mathrm{rpm})$.

\section{Optimization for BS production using BBD}

The optimization experiments were carried out to seek the enhanced amount of BS production by $\mathrm{BBD}$. $\mathrm{SM}$ concentration, $\mathrm{pH}$ and temperature were employed as a key optimization factors for the BS production. A total of 17 experiments were performed according to the BBD. The results were evaluated by applying the coefficient of determination $\left(\mathrm{R}^{2}\right)$, analysis of variance (ANOVA), and response plots. The second-order polynomial equation of the BBD was developed to fit the experimental results and identify the relevant model terms

$$
Y=\beta_{0+\sum} \beta_{\mathrm{i}} X_{\mathrm{i}}+\sum \beta_{\mathrm{i}} X_{\mathrm{i}}^{2}+\sum \beta_{\mathrm{ij}} X_{\mathrm{i}} X_{\mathrm{j}}(2)
$$

Where $\mathrm{Y}$ is the predicted response; $\beta_{0}, \beta_{\mathrm{i}}$, and $\beta_{\mathrm{ij}}$ are constant regression coefficients of the model and $\mathrm{X}_{\mathrm{i}}$ and $\mathrm{X}_{\mathrm{j}}$ represent independent variables.

\section{Extraction of biosurfactant}

After $72 \mathrm{~h}$ of fermentation bacterial cells were removed from BS containing medium by centrifugation at $10,000 \mathrm{rpm}$ for $30 \mathrm{~min}$ at $4{ }^{\circ} \mathrm{C}$. BS was extracted according to Pereira et al [30].

\section{Characterization of BS}

The surface morphology of the produced BS was visualised under the field FESEM (AURIGA, Carl Zeiss AG, Jena, Germany) after gold coating with an accelerated voltage of $10-20 \mathrm{kV}$. To identify the major types of functional groups, FT-IR and the spectrum of BS was obtained in the diffuse reflectance mode at a resolution of $4 \mathrm{~cm}^{-1}$ in $\mathrm{KBr}$ pellets on a Perkin-Elmer FT-IR spectrophotometer (Norwalk, USA) in the region of 4000-400 $\mathrm{cm}^{-1}$. 
MALDI-TOF analysis was performed on a Voyager-DE STR Biospectrometry Workstation (Applied Biosystems, Foster City, CA, USA) in a linear mode. The MALDI matrix used for the analysis was performed according to Oh et al [31].

\section{Removal of heavy metals using BS}

Removal of heavy metals was evaluated by adding BS $(250 \mathrm{mg} / \mathrm{L})$ to metal solutions containing (100-500 mg/L) of $\mathrm{Cr}, \mathrm{Pb}$ and $\mathrm{Cu}$, according to Dahrazma and Mulligan [32]. The effect of the contact time ( $48 \mathrm{~h}$ at $150 \mathrm{rpm}$ ). The $\mathrm{pH}$ of the culture broth was adjusted at $\mathrm{pH}$ 7.0 using $\mathrm{NaOH}$. Samples were withdrawn at predetermined time intervals and analyzed the metal(loid)s concentration by using inductively coupled plasma mass spectrometry (ICP, Leemans Labs, USA).

\section{Results and Discussion}

\section{Isolation and identification of heavy metal resistant bacteria for BS production}

Five morphologically different heavy metal resistant strains were isolated from the chromium contaminated soil of Ranipet, Tamil Nadu, India. The total Cr(VI) content in the soil $(\mathrm{mg} / \mathrm{kg})$ was $\mathrm{Cr}(\mathrm{VI}) 1000 \pm 5.2$. All of them were screened for BS producing efficiency and the strain RM was selected due to its high metal resistance mechanism and efficient BS producing activity. The strain RM showed a high degree of resistance to $\mathrm{Cr}(800 \mathrm{mg} / \mathrm{L}), \mathrm{Pb}(600 \mathrm{mg} / \mathrm{L})$ and $\mathrm{Cu}(550 \mathrm{mg} / \mathrm{L})$. The isolate RM showed high emulsification activity (52\%) and oil displacement activity $(6.7 \mathrm{~mm})$. The other four isolates showed less than $25 \%$ of emulsification activity. Based on the BS screening results the strain RM was chosen for further optimization of BS production and heavy metal removal applications. The 16S rRNA gene sequencing was carried out to identify the isolate RM. The 16S rDNA sequence of this

strain showed 99\% identity with Rahnella sp. The partial 16S rRNA (619 bp) of the isolate RM was deposited in GenBank (Accession Number: KX656894). A phylogenetic tree was 
derived from the partial 16S rDNA sequences of strain RM with existing sequences in the NCBI database, and the results are shown in Fig. 1. Several studies have reported the metal tolerance mechanism and the BS producing potential of Rahnella sp. [21, 33]. However, the previous studies have reported the Rahnella sp. could tolerate metal and produce BS individually. The Rahnella sp. RM showed heavy metal resistance mechanism and BS producing activity has an additional advantage for the use of the strain RM in an environmental application. The metal stress allows the Rahnella sp. RM to thrive under the abiotic conditions with diverse biological functions and productivity of BS.

\section{Growth kinetics of Rahnella sp. RM}

Till now, pure substrates such as glucose and hydrocarbonslike hexadecane, palm oil, olive oil etc have beenused for biosurfactant production [8]. In this study, SM was investigated for effective cell growth. Growth profile of the Rahnella sp. RM in the presence of different concentrations (1-5\%) of SM is presented in Fig.2. The cell growths were increased with increase of culture time by $42 \mathrm{~h}$ irrespective of SM concentration. However, they were decreased from $42 \mathrm{~h}$ of culture. Also, when SM concentration was increased, the cell growth was increased. These results indicate that cell growth of Rahnella sp. RM was strongly affected by SM concentration. The rich nutrients present in the SM had extended the log phase of growth kinetics. Our previous studies reported the nutrient properties of oil cakes and the growth profile of microorganisms [5-7]. The growth kinetics showed that the SM could be used as an alternative to the synthetic medium for the cultivation of bacteria. The presence of abundant nutrients of SM enhances the growth of bacteria as well as metabolic products synthesis. Thus, the SM was used as a substrate medium for the production of BS by fermentation.

\section{Optimization of SM, temperature, and $\mathrm{pH}$ for BS production using BBD}


SM plays an important role in the production of BS by Rahnella sp. In order to optimize physicochemical conditions for BS production, various parameters such as SM concentration, $\mathrm{pH}$ and temperature were used. The isolate $\mathrm{RM}$ showed high emulsification activity $(52 \%)$ and oil displacement activity $(6.7 \mathrm{~mm})$ in $\mathrm{SM}$ medium. To obtain the maximum BS production, effect of the variables interaction on the BS production using levels of $\mathrm{SM}$, temperature, and $\mathrm{pH}$ were determined by $\mathrm{BBD}$. The experimental results obtained from three factorial design matrix, and the model was fitted well into the second order polynomial equation of the BBD. The observed results were assessed to test the significance of regression model and the results of ANOVA are presented in Table 2 and 3. The ANOVA analysis showed that the second order polynomial equation and the relationship between designed response and the significant variables. The significance of the regression model was further confirmed by the Fishers F-test with a very low probability value ( $\mathrm{F}$ value $=32.27$ ). The value of $\mathrm{P}<0.0001$ indicated the BBD model term was significant. The fitness of the model showed with the coefficient determination value $\left(\mathrm{R}^{2}\right)$. The predicted $\mathrm{R}^{2}(0.8404)$ and adjusted $\mathrm{R}^{2}(0.9462)$ values for $\mathrm{BS}$ emulsification were in reasonable agreement with the value of $\mathrm{R}^{2}(0.9765)$, which is closer to 1.0 , indicating the better fitness of the model in the experimental data. The influence of significant variables on BS production was depicted using 3D plots (Fig. 3). The observed results illustrated that the optimization of fermentation medium enhanced the BS production with the combination of variables. The results clearly indicated that the SM could be effectively used as an alternative media for the production of BS in fermentation. The coefficients of the regression equation were calculated and the following regression equation was obtained

$\mathrm{Y}=63.80+0.38 \mathrm{~A}+0.50 \mathrm{~B}+0.12 \mathrm{C}-1.50 \mathrm{AB}-0.75 \mathrm{AC}-1.00 \mathrm{BC}-10.78 \mathrm{~A}^{2}-4.52 \mathrm{~B}^{2}-$ $6.28 C^{2}$

Where, Y stands for emulsification index, $\mathrm{A}$ is $\mathrm{SM}, \mathrm{B}$ is temperature, and $\mathrm{C}$ is $\mathrm{pH}$. 
According to the BBD model, the maximum BS emulsification was achieved at $6.0 \%$ $\mathrm{SM}, 33.5^{\circ} \mathrm{C}$ and $\mathrm{pH}$ 7.0. To verify the accuracy of the model, the BS emulsification activity (66 \%) was performed according to the predicted optimum fermentation condition. The results illustrated that the BS emulsification was $65.91 \pm 0.2 \%$, which is closely related with the predicted value of $66 \%$. The results from this study indicated that SM concentration, $\mathrm{pH}$ and temperature play a major role in the BS production from Rahnella sp. RM.

\section{Characterization of BS}

The structural morphology of the BS is shown in Fig.4. The results showed that the structural porous webs of BS. To identify the preliminary chemical compounds of BS, FT-IR was carried out to analyze the functional groups present in the BS (Fig.5). The results clearly indicated that the BS exhibited an absorption band at $3490 \mathrm{~cm}^{-1}$ of $\mathrm{N}-\mathrm{H}$ stretching. The band at $2940 \mathrm{~cm}^{-1}$ represents the aliphatic chains $\left(-\mathrm{CH}_{3}-\mathrm{CH}_{2}\right)$ of BS. A strong absorption band at $1660 \mathrm{~cm}^{-1}$ indicating $\mathrm{CO}-\mathrm{N}$ stretching and band at $1550 \mathrm{~cm}^{-1}$ indicating the presence of $\mathrm{N}-\mathrm{H}$ bond combined with $\mathrm{C}-\mathrm{N}$ stretching pattern. The FT-IR results confirmed the presence of various functional groups of the BS $[31,34,35]$. The molecular mass of the BS was measured using MALDI TOF mass spectrometry (Fig.6). The MALDI results showed the resolved groups of peaks at 1000-1575 m/z. The extensive peaks at 1062.31, 1048.26, $1468.30 ; 1483.19 \mathrm{~m} / \mathrm{z}$ indicated the structural analogs of BS. The results clearly indicated the presence of O-linked and N-linked polysaccharide moieties of BS obtained from Bacillus pumilus DSVP18 grown on potato peels [34].

\section{Removal of heavy metals using BS}

The potential of the BS obtained from Rahnella sp. RM in the removal of heavy metals, such as $\mathrm{Cr}, \mathrm{Pb}$ and $\mathrm{Cu}$ was investigated in $500 \mathrm{~mL}$ flasks containing working volume $100 \mathrm{~mL}$ of metal solution $(100-500 \mathrm{mg} / \mathrm{L})$ of $\mathrm{Cr}, \mathrm{Pb}$ and $\mathrm{Cu}$ and $250 \mathrm{mg} / \mathrm{L}$ of $\mathrm{BS}$ at $37{ }^{\circ} \mathrm{C}$ for $48 \mathrm{hr}$ at $150 \mathrm{rpm}$. The bioremediation results of heavy metals using BS were presented in Fig.7 (a-c). 
The maximum removal rate of $\mathrm{Cu}$ was observed $74.3 \%$ at the $100 \mathrm{mg} / \mathrm{L}$. However, when the $\mathrm{Cu}$ concentration was increased from $100 \mathrm{mg} / \mathrm{L}$ to $500 \mathrm{mg} / \mathrm{L}$, the total removal amount was increased from $7.43 \mathrm{mg}$ to $26.93 \mathrm{mg}$, which was about 3.62 times higher than that of 100 $\mathrm{mg} / \mathrm{L}$ of $\mathrm{Cu}$. In the case of $\mathrm{Cr}$ removal, the maximum removal rate of $\mathrm{Cr}$ was observed at $72.5 \%$ at $48 \mathrm{~h}$ at the $100 \mathrm{mg} / \mathrm{L}$. When the $\mathrm{Cr}$ concentration was increased from $100 \mathrm{mg} / \mathrm{L}$ to $500 \mathrm{mg} / \mathrm{L}$, the total removal amount was increased from $7.25 \mathrm{mg}$ to $24.35 \mathrm{mg}$, which was about 3.28 times higher than that of $100 \mathrm{mg} / \mathrm{L}$ of $\mathrm{Cu}$. whereas, the maximum removal rate of $\mathrm{Pb}$ was observed at $70.1 \%$ at $48 \mathrm{~h}$ at the $100 \mathrm{mg} / \mathrm{L}$. When the $\mathrm{Pb}$ concentration was increased from $100 \mathrm{mg} / \mathrm{L}$ to $400 \mathrm{mg} / \mathrm{L}$, the total removal amount was increased from $7.01 \mathrm{mg}$ to 25.36 $\mathrm{mg}$, which was about 3.61 times higher than that of $100 \mathrm{mg} / \mathrm{L}$. However, in the case of over $500 \mathrm{mg} / \mathrm{L}$, it was decreased to $24.60 \mathrm{mg}$. To conclude, the biosurfactant obtained from Rahnella sp. RM increased the removal of metals in the order of $\mathrm{Cu}>\mathrm{Cr}>\mathrm{Pb}$ at $100 \mathrm{mg} / \mathrm{L}$ of each metal concentration. On the other, in the case of $500 \mathrm{mg} / \mathrm{mL}$, it was increased in the order of $\mathrm{Cu}>\mathrm{Pb}>\mathrm{Cr}$. Asha $\mathrm{A}$. et al. [36] reported that rhamnolipid biosurfactant by Pseudomonas aeruginosa BS2 selectively favours mobilization of metals in the order of $\mathrm{Cr}>\mathrm{Pb}>\mathrm{Cu}$ [36]. Apart from differential removal of metals to soil, the extraction and mobilization of metals depends on various factor like stability constant of the metals of concern with the rhamnolipid [37]. The bioremediation rate of isolate Rahnella sp. RM should be strongly dependent on the population of cells at optimal growth conditions. The results also suggest that the isolate Rahnella sp. RM can survive under the high concentration of heavy metals and has been identified as a potential candidate for application in bioremediation of heavy metals in contaminated environments. De Franca et al. [3] reported that maximum removal rate of $\mathrm{Cu}$ was at $48 \mathrm{~h}$. It is suggested that the presence of functional groups of BS may promote the chelation of the metal(loid)s. Mulligan et al. [12, 38] reported that the carboxylic groups of amino acids significantly contribute to metal chelation by 
surfactant. However, further work will address the interactions between the metal ions, and the BS in metal removal mechanism. The application of BS in heavy metal removal is potential alternative for chemical surfactants.

\section{Conclusion}

A new strain, heavy metal resistant Rahnella sp. RM is isolated from chromiumcontaminated subsurface soil and is found to produce large quantities of BS and remove heavy metals using biosurfactant. To our knowledge, this might be the first study to screen heavy metal resistant bacteria and its ability to remediate heavy metal using biosurfactant. This study demonstrated the efficient BS emulsification was achieved using SM as an alternative substrate in fermentation. Utilization of these by-products in biotechnological production processes has importance in economical and ecological fields. For that reason, the feasibility of usage of these wastes as substrates to produce valuable biotechnological products has gained importance, recently. The BS produced from Rahnella sp. RM showed the maximum emulsification activity $(66 \%)$ at $6 \% \mathrm{SM}$ and $33.5^{\circ} \mathrm{C}$ culture in $\mathrm{pH} 7.0$. The bioremediation rates using the biosurfactant increased in the following order: $\mathrm{Cu}(74.3 \%)>$ $\mathrm{Cr}(72.5 \%)>\mathrm{Pb}(70.1 \%)$. The morphological studies, structural and functional analysis revealed that the nature of BS. Furthermore, the BS has high potential to be used in bioremediation of metal(loid)s.

\section{References}

1. Sun YB, Zhou QX, Xu YM, Wang L, Liang XF (2011) Phytoremediation for cocontaminated soils of benzo [a] pyrene (B[a] P) and heavy metals using ornamental plant Tagetes patula. J Hazard Mater 186:2075-2082

2. Borbely G., Nagy E (2009) Removal of zinc and nickel ions by complexation-membrane filtration process from industrial wastewater. Desalination $240: 218-226$ 
3. de Franca IWL, Lima AP, Lemos JAM, Lemos CGF, MacielMelo VM, de Santana HB, Goncalves LRB (2015) Production of a biosurfactant by Bacillus subtilis ICA56 aiming bioremediation of impacted soils. Catal Today 255:10-15

4. Ok YS, Kim SC, Kim DK, Skousen JG, Lee JS, Cheong YW, Kim SJ, Yang YE (2011) Ameliorants to immobilize $\mathrm{Cd}$ in rice paddy soils contaminated by abandoned metal mines in Korea. Environ Geochem Heth 33:23-30

5. Govarthanan M, Lee GW, Park JH, Kim JS, Lim SS, Seo SK, Cho M, Myung H, KamalaKannan S, Oh BT (2014) Bioleaching characteristics, influencing factors of $\mathrm{Cu}$ solubilisation and survival of Herbaspirillumsp. GW103 in $\mathrm{Cu}$ contaminated mine soil. Chemosphere 109:42-48

6. Govarthanan M, Lee KJ, Cho M, Kim JS, Kamala-Kannan S, Oh BT (2013) Significance of autochthonous Bacillus sp. KK1 on biomineralization of lead in mine tailings. Chemosphere 90:2267-2272

7. Govarthanan M, Park SH, Park YJ, Myung H, Krishnamurthy RR, Lee SH, Lovanh N, Kamala-Kannan S, Oh BT (2015) Lead biotransformation potential of allochthonous Bacillus sp. SKK11 with sesame oil cake extract in mine soil. RSC Adv 5:54564-54570

8. Ismail W, Al-Rowaihi IS, Al-Humam AA, Hamza RY, Nayal AM, Bououdina M (2013) Characterization of a lipopeptide biosurfactant produced by a crude-oil-emulsifying Bacillus sp. I-15. Int Biodeterior Biodegrad 84:168-178

9. Kang CH, Kwon YJ, So JS (2016) Bioremediation of heavy metals by using bacterial mixtures. Ecol Eng 89:64-69 
10. Liu H, Guo S, Jiao K, Hou J, Xie H, Xu H (2015) Bioremediation of soils cocontaminated with heavy metals and 2, 4, 5-trichlorophenol by fruiting body of Clitocybe maxima. J Hazard Mater 294:121-127

11. Taiwo AM, Gbadebo AM, Oyedepo JA, Ojekunle ZO, Alo OM, Oyeniran AA, Onalaja OJ, Ogunjimia D, Taiwo OT (2016) Bioremediation of industrially contaminated soil using compost and plant technology. J Hazard Mater 304:166-172

12. Mulligan CN (2005) Environmental applications for biosurfactants. Environ Pollut $133: 183-198$

13.Grugurina I, Mariotti F, Fogliano V, Gallo M, Scaloni A, Iacobellis N, LoCantore P, Mannina L, Van Axel Castelli V, Grecco ML, Graniti A (2002) A new syringopeptide produced by bean strains of Pseudomonas syringaepv. syringae. Biochim Biophys Acta 1597:81-90

14. Kim HS, Yoon BD, Lee CH, Suh HH, Oh HM, Katsuragi T, Tani Y (1997) Production and properties of a lipopeptide biosurfactant from Bacillus subtilis C9. J Ferment Bioeng $84: 41-46$.

15. Morikawa M, Daido H, Takao T, Marato S, Shimonishi Y, Imanaka T (1993) A new lipopeptide biosurfactant produced by Arthrobacter sp. strain MIS 38. J Bacteriol 175: 6459-6466

16. Roongsawang N, Thaniyavarn J, Thaniyavarn S, Kameyama T, Haruki M, Imanaka T, Morikawa M, Kanaya S (2002) Isolation and characterization of a halotolerant Bacillus subtilis BBK-1 which produces three kinds of lipopeptides: bacillomycin L, plipastatin, and surfactin. Extremophil 6:499-506.

17. Steller S, Vater J (2000) Purification of fengycin synthetase multienzyme system from Bacillus subtilis b213. J Chromatogr B 737:267-275 
18. Tuleva B, Christova N, Cohen R, Antonova D, Todorov T, Stoineva I (2009) Isolation and characterization of trehalose tetraester biosurfactants from a soil strain Micrococcus luteus BN56. Process Biochem 44:135-141

19. Yakimov M, Timmis KN, Wray V, Fredrickson HL (1995) Characterization of a new lipopeptide surfactant produced by thermotolerant and halotolerant subsurface Bacillus licheniformis BAS 50. Appl Environ Microbiol 61:1706-1713

20. He H, Ye Z, Yang D, Yan J, Xiao L, Zhong T, Yuan M, Cai X, Fang Z, Jing Y (2013) Characterization of endophytic Rahnella sp. JN6 from Polygonum pubescens and its potential in promoting growth and $\mathrm{Cd}, \mathrm{Pb}, \mathrm{Zn}$ uptake by Brassica napus. Chemosphere 90:1960-1965

21. Smułek W, Zdarta A, Guzik U, Bajorek BD Kaczorek E (2015) Rahnella sp. strain EK12: Cell surface properties and diesel oil biodegradation after long-term contact with natural surfactants and diesel oil. Microbiol Res 176:38-47

22. Kiran GS, Thomas TA, Selvin J, Sabarathnam B Lipton AP (2010) Optimization and characterization of a new lipopeptide biosurfactant produced by marine Brevibacterium aureum MSA13 in solid state culture. Bioresource Technol 101:2389-2396

23. Ramana KV, Karanth NG (1989) Factors affecting biosurfactant production using Pseudomonas aeruginosa CFTR-6 under submerged conditions. J Chem Technol Biotechnol 45:249-257

24.Anjum F, Gautam G, Edgard G, Negi S (2016) Biosurfactant production through Bacillus sp. MTCC 5877 and its multifarious applications in food industry. Bioresource Technol 213:262-269 
25. Nalini S, Parthasarathi R (2014) Production and characterization of rhamnolipids produced by Serratia rubidaea SNAU02 under solid-state fermentation and its application as biocontrol agent. Bioresource Technol 173:231-238

26. Bhange K, Chaturvedi V, Bhatt R (2016) Simultaneous production of detergent stable keratinolytic protease, amylase and biosurfactant by Bacillus subtilis PF1 Using agro industrial waste. Biotechnol Rep 10:94-104

27. Kamala-Kannan S, Lee KJ, Krishnamoorthy R, Purusothaman A, Shanthi K, Rao NR (2007) Aerobic chromate reducing Bacillus cereus isolated from the heavy metal contaminated Ennore Creek sediment, north of Chennai, Tamil Nadu, south east India. Res Microbiol 2:133-140

28. Paraszkiewicz K, Kanwal A, Dlugonski J (1992) Emulsifier production by steroid transforming filamentous fungus Curvularia lunata, growth and product characterization. J Biotechnol 92:287-294

29. Banaszkiewicz T (2000) Nutritive value of new rape cultivars stated in the tests for broiler chickens, Thesis University of Podlasie.

30. Pereira JFB, Gudina EJ, Costa R, Vitorino R, Teixeira JA, Outinho JAP, Rodrigues LR (2013) Optimization and characterization of biosurfactant production by Bacillus subtilis isolated towards microbial enhanced oil recovery applications. Fuel 111:259-268

31. Oh BT, Hur H, Lee KJ, Shanthi K, Soh BY, Lee WJ, Myung H, Kamala-Kannan S (2011) Suppression of phytophthora blight on pepper by bacilli isolated from brackish environment. Biocontrol Sci Tech 21:1297-1311

32. Dahrazma A, Mulligan CN (2007) Investigation of the removal of heavy metals from sediments using rhamnolipid in a continuous flow configuration. Chemosphere 69:705711 
33. Saranya P, Swarnalatha S, Sekaran G (2014) Lipoprotein biosurfactant production from an extreme acidophile using fish oil and its immobilization in nanoporous activated carbon for the removal of $\mathrm{Ca}^{2+}$ and $\mathrm{Cr}^{3+}$ in aqueous solution. RSC Adv 4:34144-34155

34. Sharma D, Ansari MJ, Gupta S, Ghamdi A, Pruthi P, Pruthi V (2015) Structural characterization and antimicrobial activity of a biosurfactant obtained from Bacillus pumilus DSVP18 grown on potato peels. Jundishapur J Microbiol 8:21257-2160

35. Zou C, Wang M, Xing Y, Lan G, Ge T, Yan X, Gu T (2014) Characterization and optimization of biosurfactants produced by Acinetobacter baylyi ZJ2 isolated from crude oil-contaminated soil sample toward microbial enhanced oil recovery applications. Biochem Eng J 90:49-58

36. Asha A, Juwarkar Kirti V, Dubey Anupa N, Sanjeev Kumar S (2008) Bioremediation of multi-metal contaminated soil using Biosurfactant. Indian J Microbiol 48:142-146

37. Ochoa-Loza FJ, Artiola JF, Maier RM (2001) Stability constants for the complexation of various metals with a rhamnolipid biosurfactant. J Environ Qual 30:479-485

38. Mulligan CN, Yong RN, Gibbs BF, James S, Bennett HPJ (1999) Metal removal from contaminated soil and sediments by the biosurfactant surfactin. Environ Sci Technol $33: 3812$ 


\section{Figure legends}

Fig. 1A neighbour-joining tree constructed using Mega 6.0 showing the phylogenetic relationship of $16 \mathrm{~S}$ rDNA sequence of Rahnella sp. RM from closely related sequences from GenBank. Accession numbers at the GenBank of National Centre for Biotechnology Information (NCBI) are shown in parenthesis.

Fig. 2 Growth kinetics of Rahnella sp. RM at various concentration of soybean meal (SM). Error bars indicate standard deviation of means.

Fig. 3 Response surface 3-D plots of emulsification activity of biosurfactants produced by Rahnella sp. RM.

Fig. 4 FE-SEM micrographs of BS produced by Rahnella sp. RM.

Fig. 5 FTIR spectra of BS produced by Rahnella sp. RM.

Fig. 6 MALDI-TOF MS spectra of BS produced by Rahnella sp. RM.

Fig. 7 (a) Removal of $\mathrm{Cr}$, (b) Removal of $\mathrm{Cu}$, (c) Removal of $\mathrm{Pb}$ by using $\mathrm{BS}$ in batch cultures. Error bars indicate standard deviation of means. 


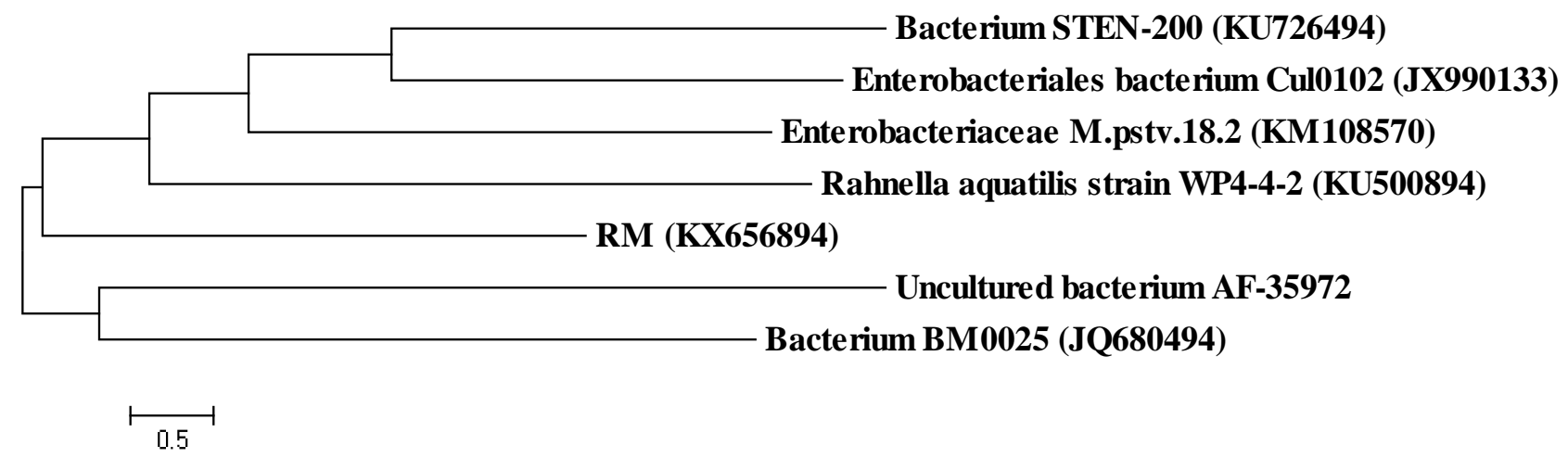

Fig.1

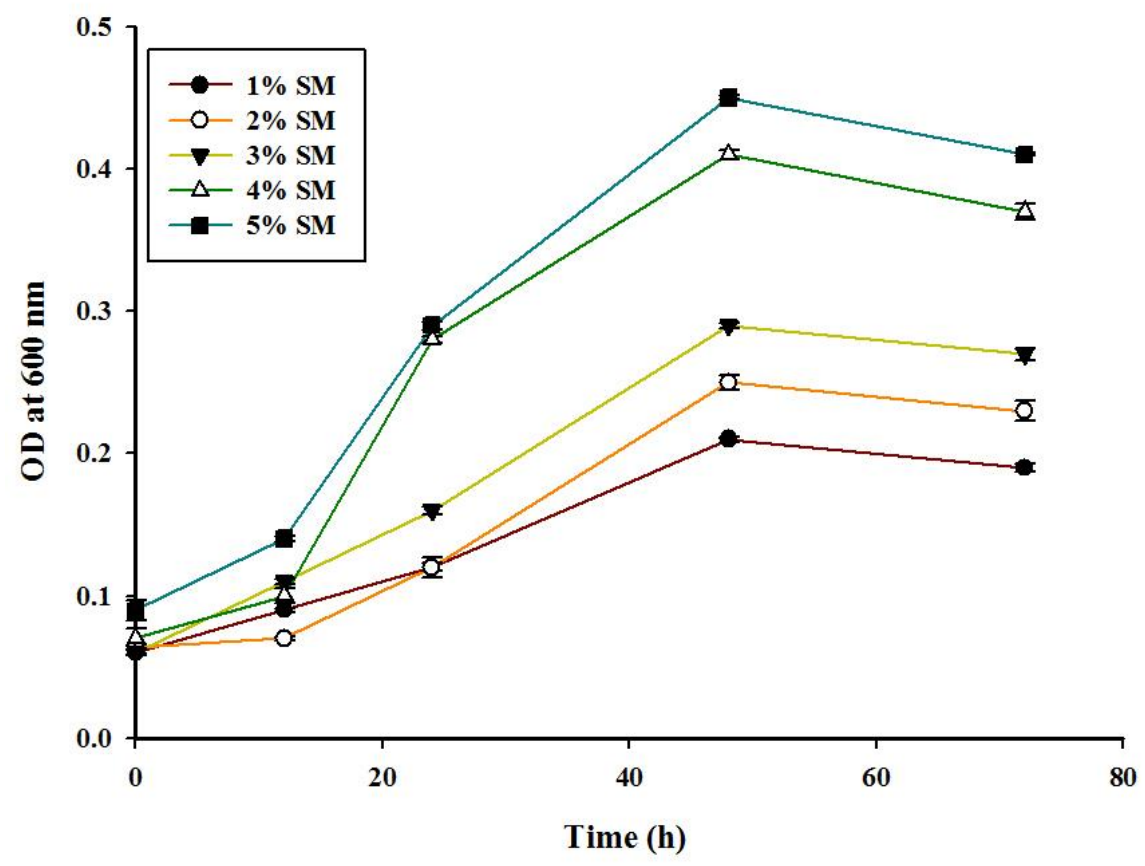

Fig.2 

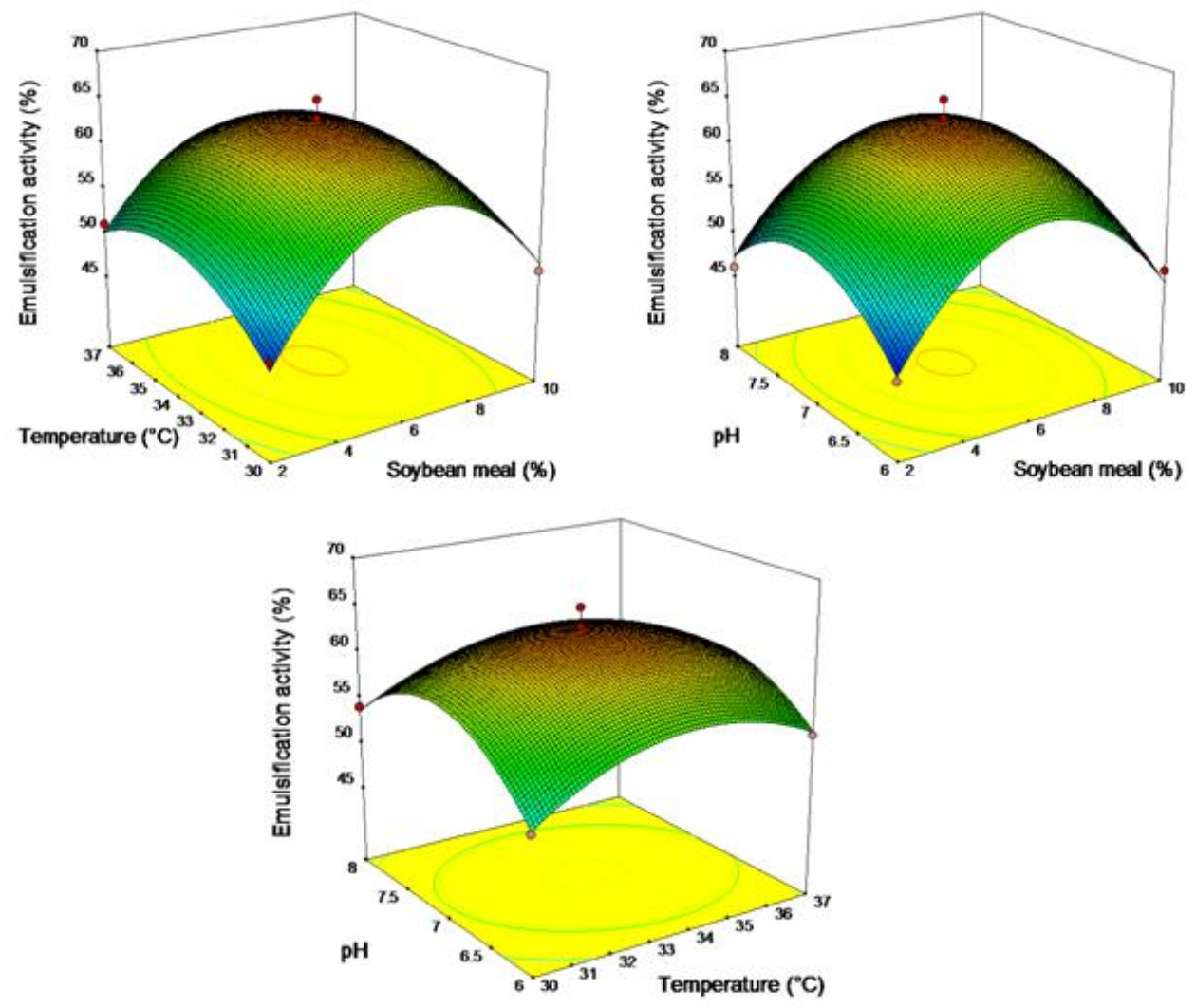

Fig.3

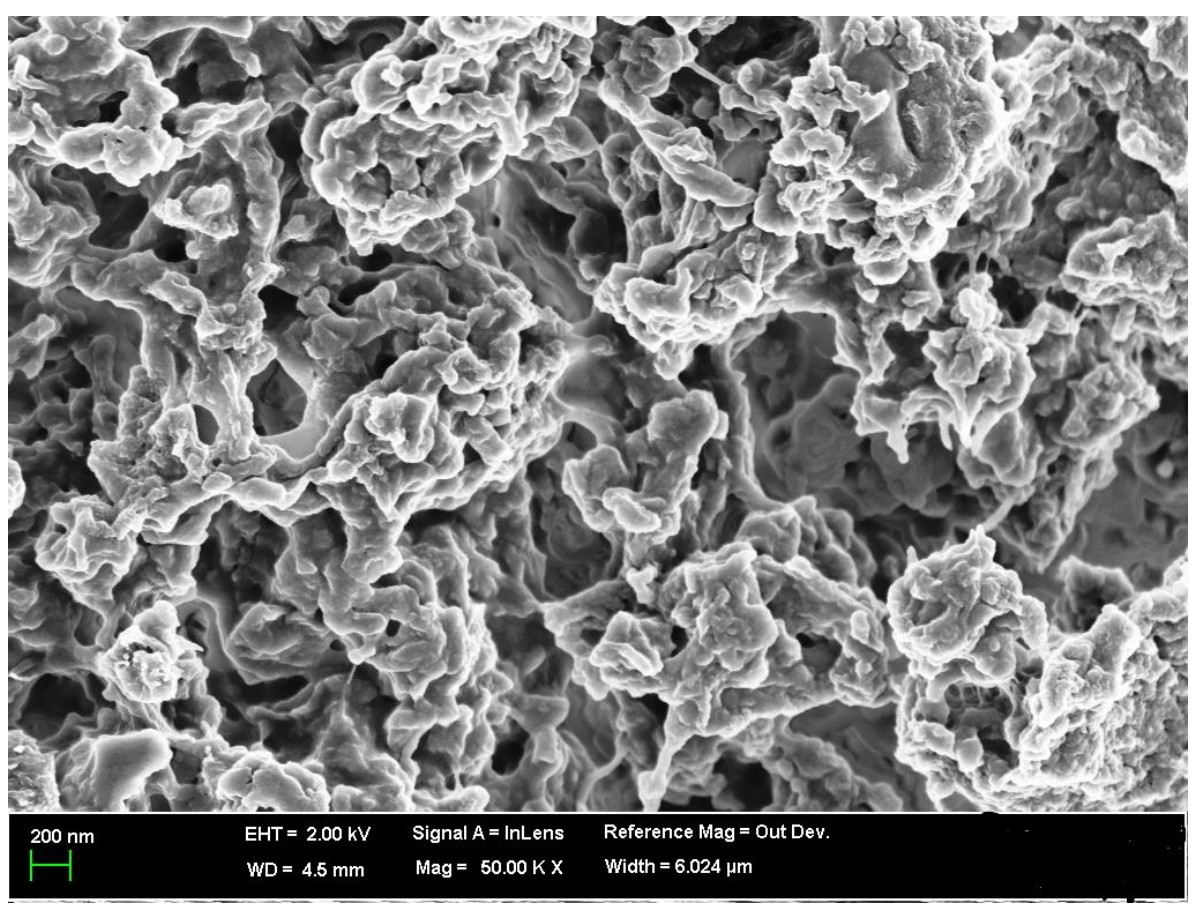


Fig.4

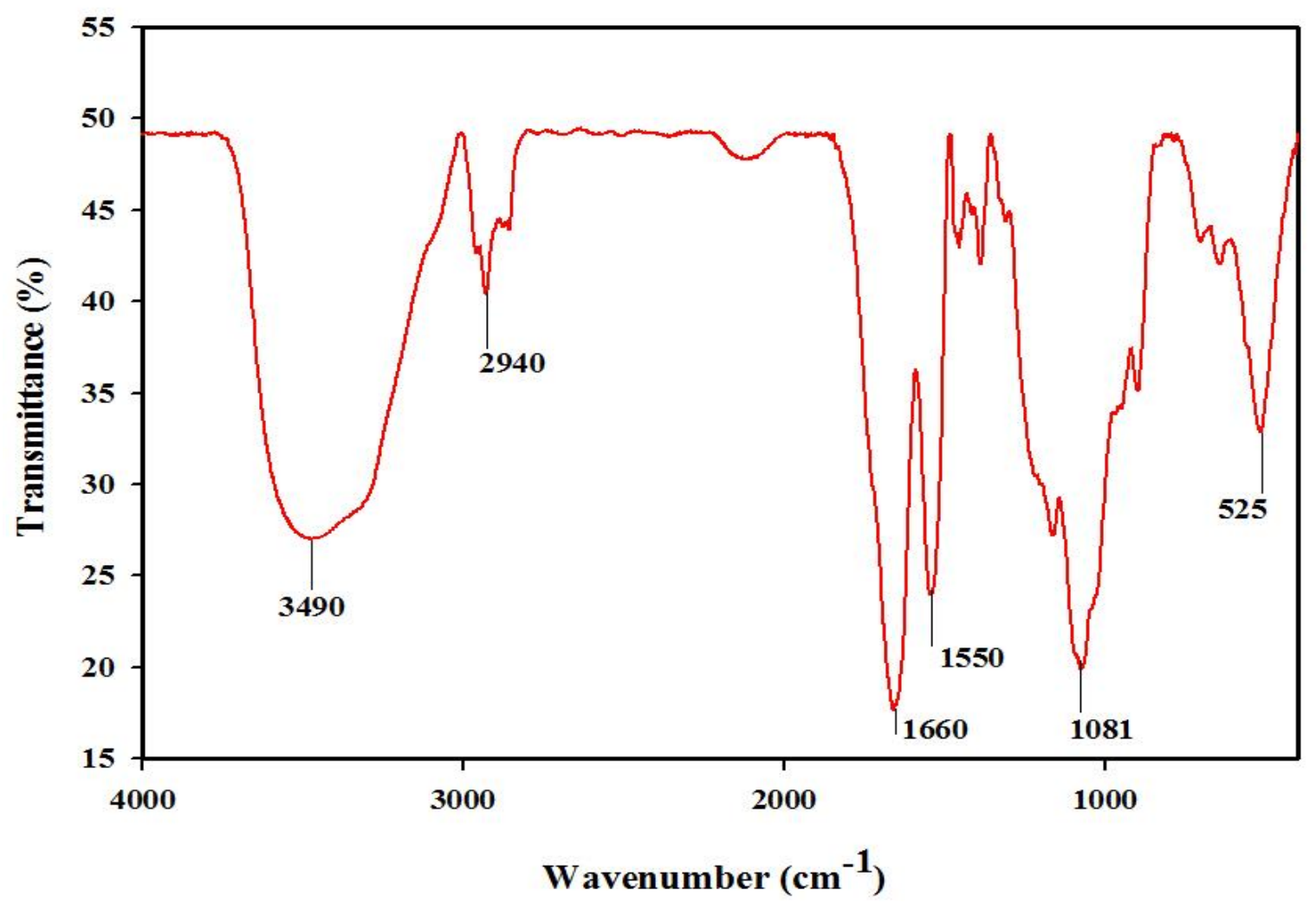

Fig.5 


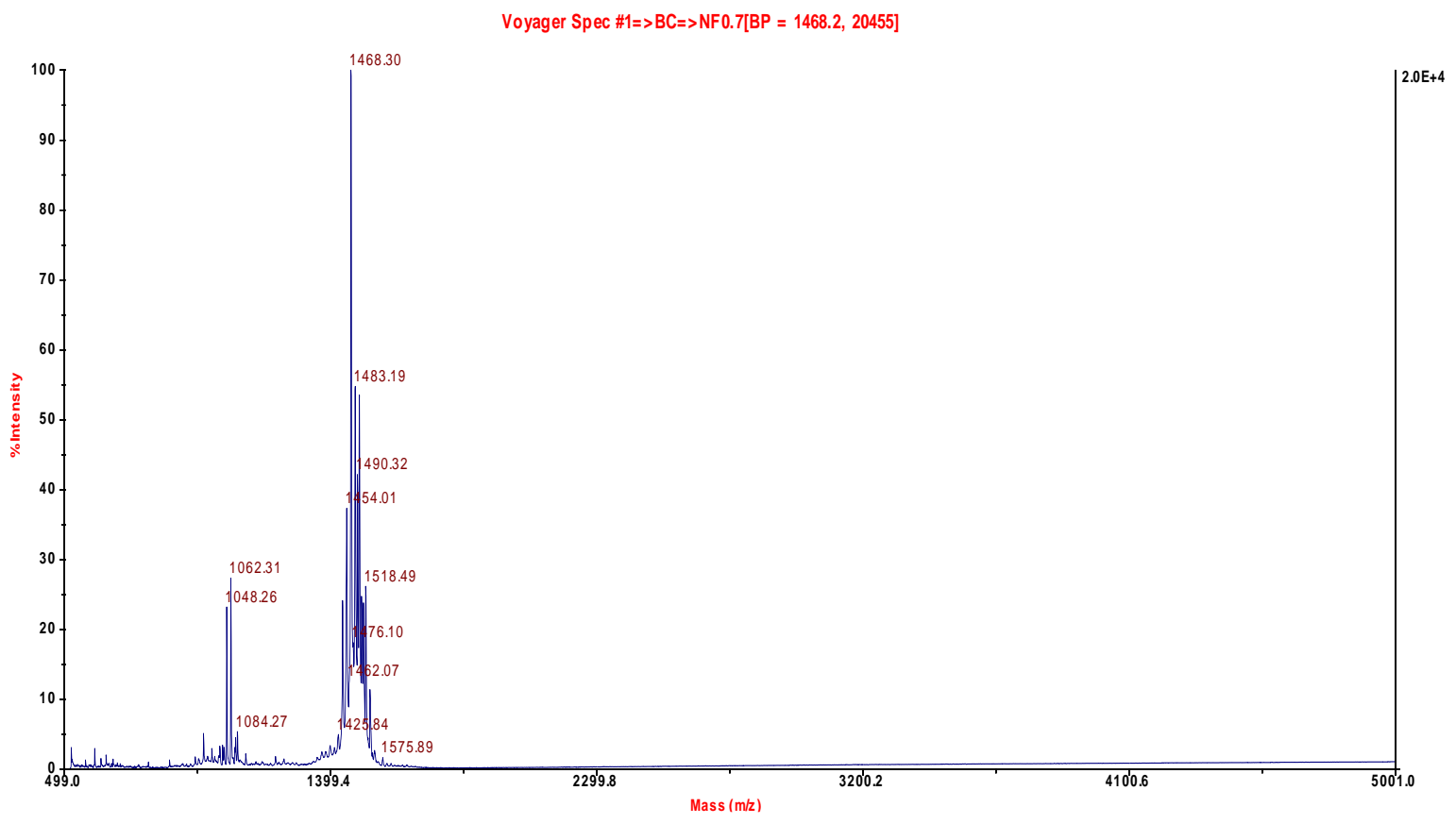

Fig.6

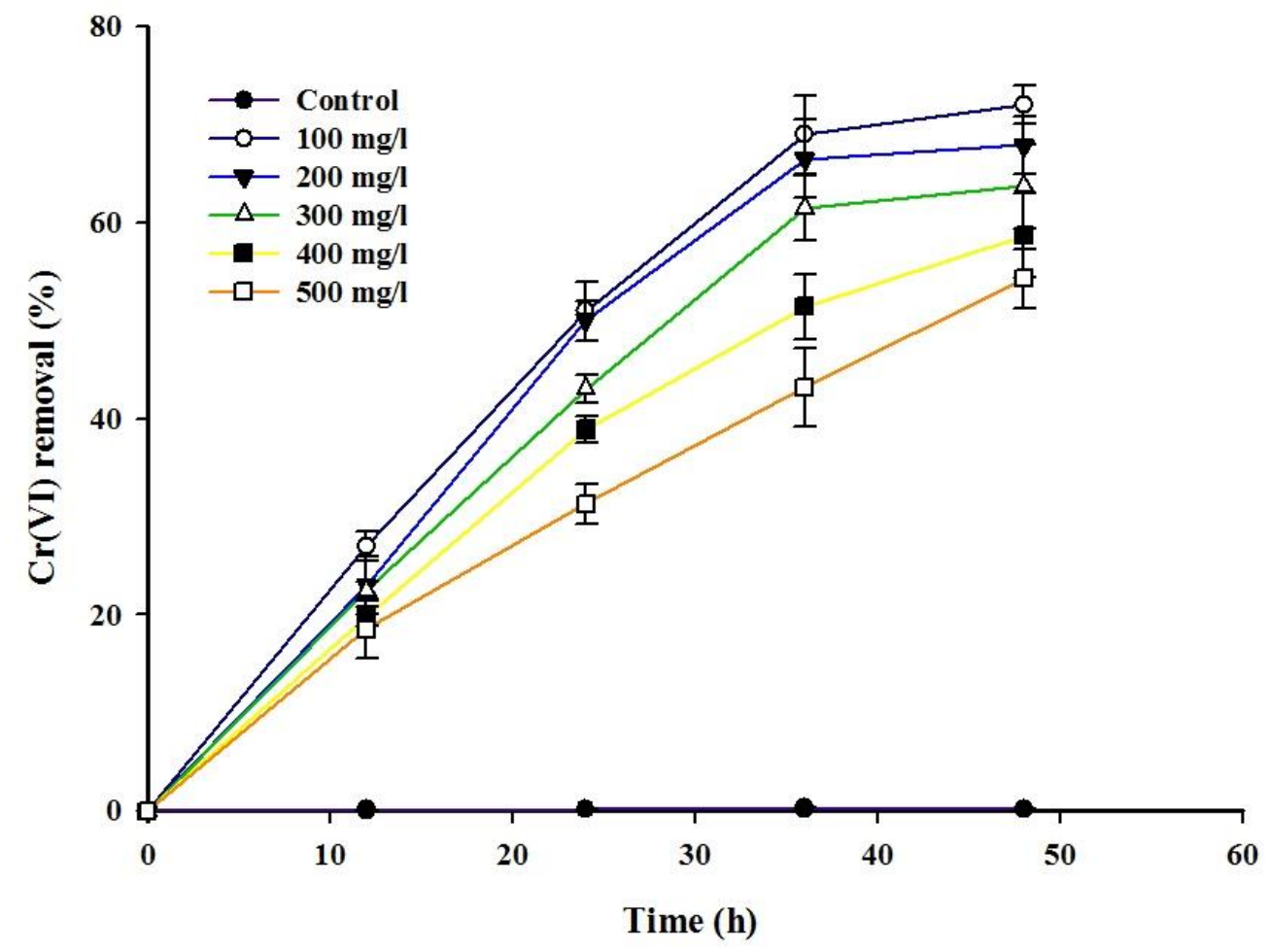

Fig.7(a) 


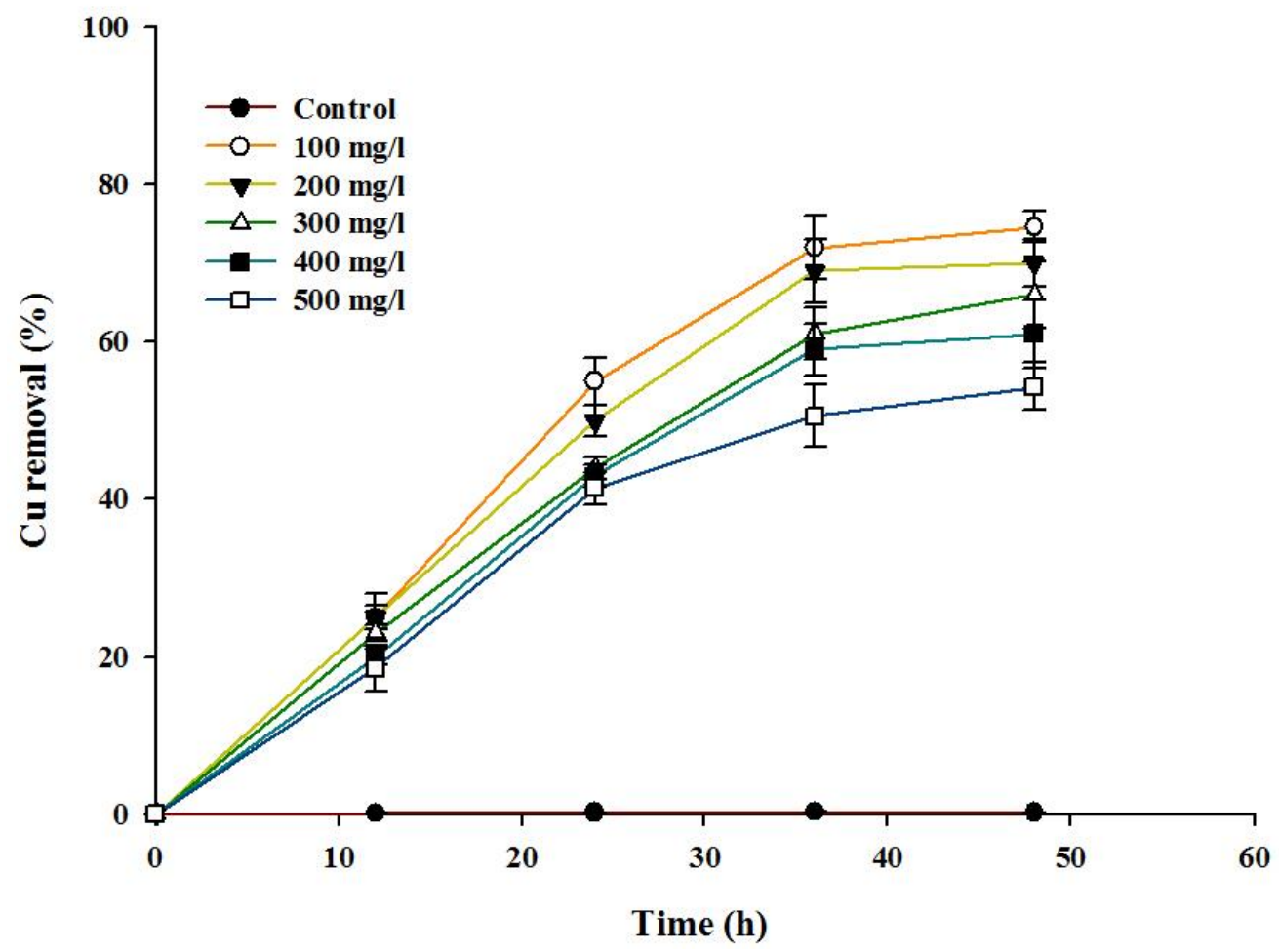

Fig.7 (b)

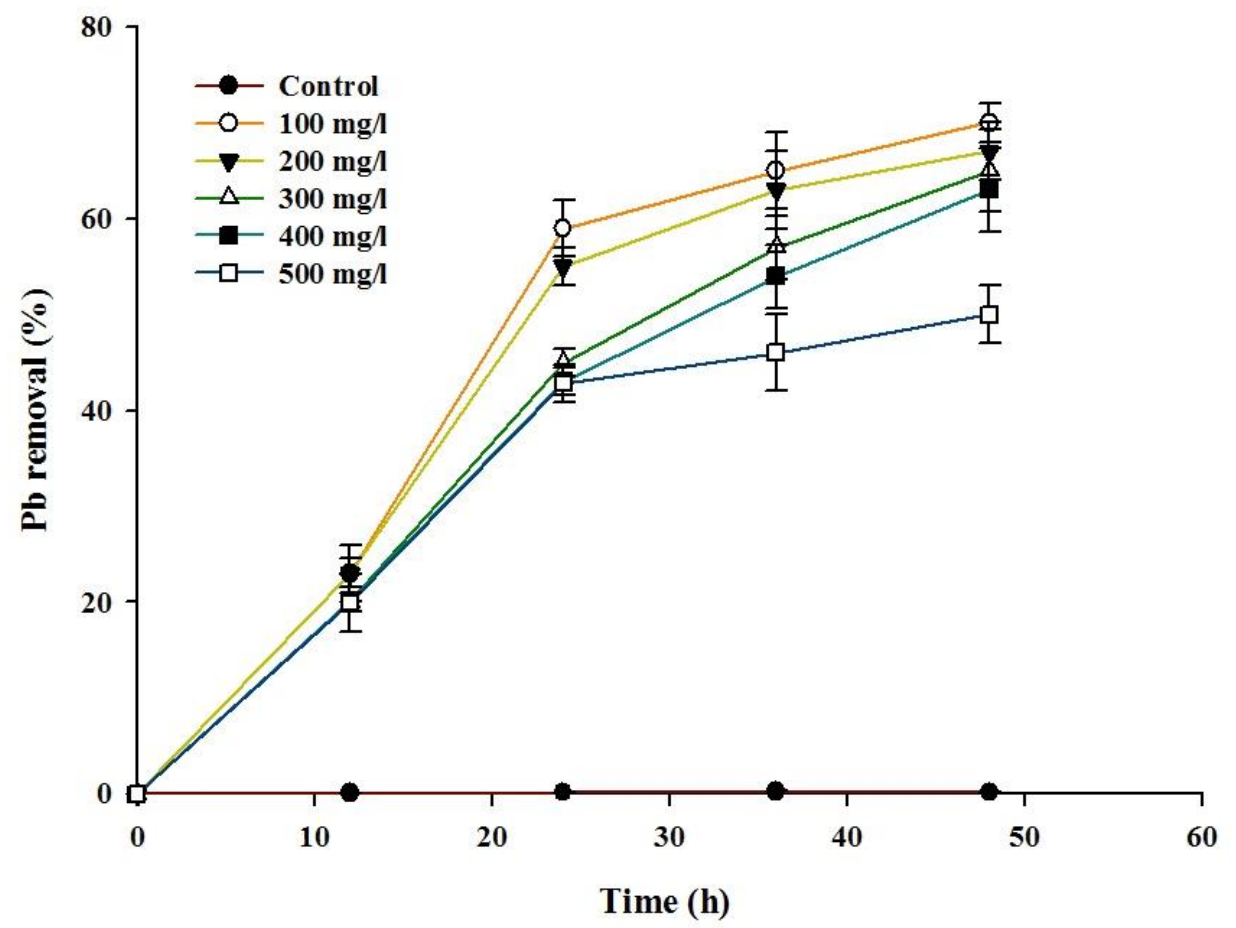

Fig. 7 (c) 
Table legends

Table 1. Nutrient Composition of SM

Table 2. Box-Behnken design for the variables and the experimental observed responses

Table 3. Analysis of variance (ANOVA) for the response surface quadratic model 
Table 1.

\begin{tabular}{|c|c|}
\hline Chemical Components & Quantity (\%) \\
\hline N-free extractive & 31.82 \\
\hline Crude protein & 44.40 \\
\hline Crude fibre & 6.75 \\
\hline Ash & 6.65 \\
\hline Neutral detergent fiber & 15.51 \\
\hline Acid detergent fiber & 9.5 \\
\hline Crude fat & 2.18 \\
\hline Starch & 6.3 \\
\hline
\end{tabular}


Table 2

\begin{tabular}{|c|c|c|c|c|}
\hline S.NO & Soybean meal concentration (\%) & Temperature $\left({ }^{\circ} \mathrm{C}\right)$ & $\mathrm{pH}$ & Emulsification (\%) \\
\hline 1 & 2 & 37 & 7 & 51 \\
\hline 2 & 6 & 33.5 & 7 & 64 \\
\hline 3 & 6 & 30 & 6 & 51 \\
\hline 4 & 10 & 30 & 7 & 49 \\
\hline 5 & 6 & 37 & 6 & 54 \\
\hline 6 & 10 & 33.5 & 8 & 47 \\
\hline 7 & 6 & 33.5 & 7 & 64 \\
\hline 8 & 2 & 30 & 7 & 47 \\
\hline 9 & 6 & 33.5 & 7 & 66 \\
\hline 10 & 6 & 33.5 & 7 & 64 \\
\hline 11 & 10 & 37 & 7 & 47 \\
\hline 12 & 10 & 33.5 & 6 & 49 \\
\hline 13 & 6 & 30 & 8 & 54 \\
\hline 14 & 6 & 37 & 8 & 53 \\
\hline
\end{tabular}




\begin{tabular}{|l|l|l|l|l|}
\hline 15 & 6 & 33.5 & 7 & 61 \\
\hline 16 & 2 & 33.5 & 8 & 46 \\
\hline 17 & 2 & 33.5 & 6 & 45 \\
\hline
\end{tabular}

Table 3.

\begin{tabular}{|l|c|c|c|c|c|}
\hline Source & Sum of Squares & Df & Mean square & $F$ value & $p$-value \\
\hline Model & 831.83 & 9 & 92.43 & 32.27 & $<0.0001^{\mathrm{a}}$ \\
\hline $\mathrm{A}$ & 1.13 & 1 & 1.13 & 0.39 & 0.5507 \\
\hline $\mathrm{B}$ & 2.00 & 1 & 2.00 & 0.70 & 0.4310 \\
\hline $\mathrm{C}$ & 0.13 & 1 & 0.13 & 0.044 & 0.8405 \\
\hline $\mathrm{AB}$ & 9.00 & 1 & 9.00 & 3.14 & 0.1196 \\
\hline $\mathrm{AC}$ & 2.25 & 1 & 2.25 & 0.79 & 0.4049 \\
\hline $\mathrm{BC}$ & 4.00 & 1 & 4.00 & 1.40 & 0.2759 \\
\hline $\mathrm{A}^{2}$ & 488.84 & 1 & 488.84 & 170.67 & $<0.0001$ \\
\hline $\mathrm{B}^{2}$ & 86.21 & 1 & 86.21 & 30.10 & 0.0009 \\
\hline $\mathrm{C}^{2}$ & 165.79 & 1 & 165.79 & 57.88 & 0.0001 \\
\hline Residual & 20.05 & 7 & 2.86 & - & - \\
\hline Lack of Fit & 7.25 & 3 & 2.42 & 0.76 & 0.5743 \\
\hline Pure Error & 12.80 & 4 & 3.20 & - & - \\
\hline
\end{tabular}


a- significant 